Available online at: http://proceeding.rsfpress.com/index.php/ic-smart/index

Proceeding on International Conference of Science Management Art Research Technology

(IC-SMART)

Volume 1 Number 1 (2020): 33-43

\title{
The Potential of CO2 Injection on Enhanced Oil Recovery Method for Oil Fields in Indonesia
}

\author{
Rini Setiati, Gilbert Soenarjo, Ixora Karundeng, Vicky Dimas Widoseno \\ Petroleum Engineering Department, Faculty of Earth and Energy Technology, Trisakti \\ University, Jakarta, Indonesia \\ Email address rinisetiati@trisakti.ac.id; Email address gilbertsunaryo@gmail.com; Email \\ address ikarundeng@gmail.com; Email address vickydimasw@ymail.com
}

\begin{abstract}
Indonesia is one of the countries that have large oil and gas reserves. So far, primary and secondary oil recovery can only produce around 20\%-40\% of reservoir reserves in Indonesia, so there is a large amount of oil potentially remaining in reservoirs. One of the Enhanced Oil Recovery (EOR) methods is $\mathrm{CO} 2$ injection because there are many sources of $\mathrm{CO} 2$ gas in oil fields in Indonesia. The purpose of this study was to determine the performance of the CO2 injection mechanism method, which can make hydrocarbon fluid miscibility and increase the recovery factor of oil wells. The methodology in this study is a literature review that discusses oil field data in Indonesia. Screening criteria use several parameters, including reservoir pressure and minimum miscibility pressure. Field data is then calculated and predicted using simulations. From the results of the simulation, calculations carried out there are six oil field areas that have the potential for $\mathrm{CO} 2$ injection in an effort to improve oil recovery, namely in the East Kalimantan, West Java, and South Sumatra areas, with recovery factors ranging from 50\% - 90\% of the original oil in place (OOIP). ). CO2 flooding has a good potential to be implemented in oil fields in Indonesia because there are many sources of CO2, easy to obtain, very good for increasing production rates in reservoirs with heavy and light oil content, and can reduce the results of environmental pollution from gas emissions.
\end{abstract}

Keywords: $\mathrm{CO} 2$ flooding, enhanced oil recovery, environmental pollution, minimum miscibility pressure, recovery factor

\section{INTRODUCTION}

This is an open access article under the CC-BY-NC license

The level of primary and secondary oil acquisition at the present time is at $20-40 \%$ of total OOIP, which indicates that there is a large potential of oil leftovers in the reservoir. Enhanced Oil Recovery is a well-known technology in the oil industry, which is utilized to increase oil production acquisition by transforming fluid and reservoir rock characteristics. This EOR technology is conducted by injecting a fluid or gas into the production well. To improve oil and gas production in Indonesia, there are two commonly known steps, which are extensification and intensification. The Extensification step is an effort to improve oil recovery by conduction exploration or opening new refineries. Meanwhile, intensification is a means to improve oil and gas production by increasing the 
recovery factor by utilizing advanced technology to recover oil or what is known as Enhanced Oil Recovery (EOR).

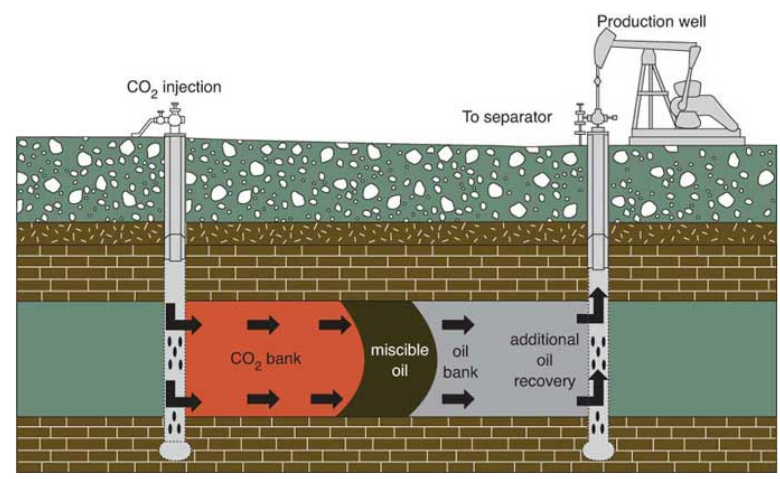

Figure 1. Carbon dioxide miscible flooding (Annual Report 2005)

The objective of this research is to acknowledge the performance of the $\mathrm{CO}_{2}$ injection mechanism method that can create hydrocarbon fluid miscibility and improve recovery factors on oil refineries. Oil acquisition reduction cases are frequently happening because of the depleting number of oil due to continuous exploitations, even though oil is still available on the spot. However, it becomes more difficult to produce oil in the refinery because its oil containment and reservoir pressure are decreasing. Naturally, the production level of oil acquisition will get lower along the time. That is why technology to maintain a high level of production is required. If the situation is maintained, oil production will get lower and accelerate the end of production. Before it happens, a measured step is required to recovery production to the expected level. The selection of the applied method should be adapted to the presented condition in the field. One of the known EOR methods is $\mathrm{CO}_{2}$ injection. By the existence of this method, the operating period of refineries can be improved, and in the end, it will also increase the profitability of oil refineries. The production level of oil refineries eventually will experience a decrease after its peak period. There are several efforts that can be conducted to maintain or to improve production rate when secondary recovery is no longer effective. However, the procedure mentioned above is aimed to improve short-term production. Meanwhile, for longterm improvement, it is possible to apply tertiary recovery by gas injection.

\section{LITERATURE REVIEW}

The physical element of $\mathrm{CO}_{2}$ injection operational can be utilized to illustrate how the process works. First, the pipe channel $\mathrm{CO}_{2}$ into the field with high pressure and density according to the requirement of the reservoir. $\mathrm{CO}_{2}$ is then channeled into the injection well that is strategically placed in the good pattern to optimize the sweeping reservoir area. The injected $\mathrm{CO}_{2}$ enters the reservoir and move through rocks' pore and contacting crude leftover droplets and miscible with the oil to form new oil accumulation, which is swept into the production wells.

In production wells, the well manifold allows testing on each well to see how many oil, gas, and water can be produced in each location. The produced liquid is then separated with produced gas that includes $\mathrm{CO}_{2}$. When the injected gas is starting to break through the production well location, it needs to be further processed. Every $\mathrm{CO}_{2}$ produced needs to be separated from the natural gas and recompressed for reinjection process with additional $\mathrm{CO}_{2}$. In some situations, and the produced 
formation water is separated and processed to be re-injected consecutively with $\mathrm{CO}_{2}$ injection. This technique is conducted to improve swiping efficiency (WAG process) (NETL, 2010).

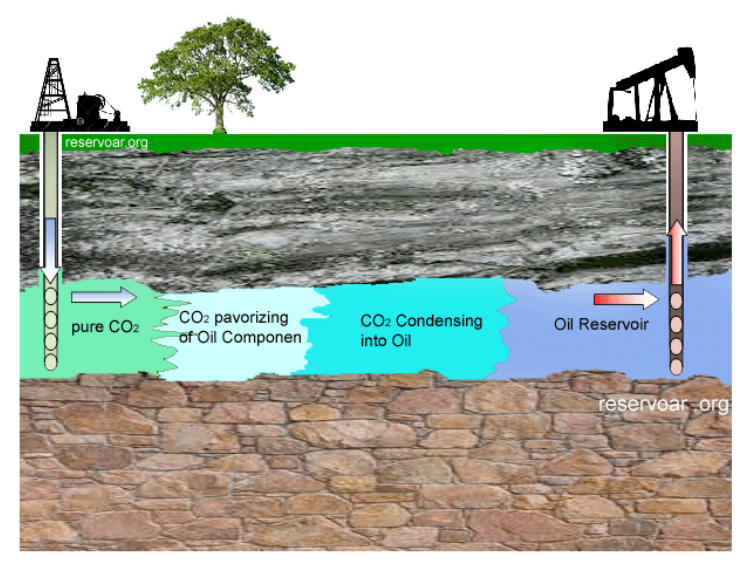

Figure 2. A Scheme of EOR Carbon Dioxide Injection Process (Khalil \& Biyanto, 2018)

In a mixed $\mathrm{CO}_{2}$ gas injection method, there are two types of miscibility contacts, which are First Contact Miscibility, where $\mathrm{CO}_{2}$ injection is conducted with a single test by determining pressure at a higher level, and Multi-Contact Miscibility which is a $\mathrm{CO}_{2}$ injection conducted on several times until it reaches mixing point. There are several methods to determine TTM pressure, which are by using laboratory slim tube test, correlation calculation, and slim tube simulation. There are many correlations that can be utilized based on the critical point calculation of a simplified multicomponent system on a pseudo component. Generally, a correlation can only predict a decent minimum mixing pressure on a certain range of a crude oil composition where the correlation itself is developed. There are several correlation methods mentioned by a number of experts, for example, Hlm Josendal correlation, Yellig Metcalfe correlation (1980), Cronquist et al. correlation (1981), National Petroleum Council correlation (2001), and Ellisa M. EIM Shokkir correlation (2006). These correlation methods possess different factors on each correlation. For example, Cronquist et al. only utilizes temperature in the TTM calculation factor. In 2006, M. El-M Shokkir managed to discover a correlation that can calculate TTM value, which is influenced by $\mathrm{CO}_{2}$ purity. The factors utilized in this correlation are oil composition and temperature (Setiati, 2016).

Oil recovery improvement concurs with different techniques, one of which is by injecting $\mathrm{CO}_{2}$ in permeable and light-oil reservoirs. This $\mathrm{CO}_{2}$ injection can improve $10 \%$ to $20 \%$ of recovery factors (Huang, Yang, Liao, \& Zeng, 2015). Besides that, this $\mathrm{CO}_{2}$ injection can also lower atmosphere gas emission by conserving $\mathrm{CO}_{2}$ inside the reservoir. The miscible gas injection also indicates that the moving gas can be mixed with oil on reservoir, whether on the first contact or on the next several contacts, which in turn will improve sweeping and volumetric displacement efficiencies (Ev and Ed). A transitional zone will develop between the oil reservoir and the displaced gas, where the injection ability of gas will depend on reservoir pressure, temperature, and oil formation factor natures. $\mathrm{CO}_{2}$ injection contains two mechanisms:

$\mathrm{CO}_{2}$ Miscible Mechanism

The miscible process happens when the reservoir pressure is higher than Minimum Miscibility Pressure (MMP), which causes the injected $\mathrm{CO}_{2}$ to be highly mixed with crude oil $\left(\mathrm{CO}_{2}\right.$ and oil in the reservoir form a single-phase). When reservoir pressure is above MMP, miscibility between $\mathrm{CO}_{2}$ and oil is achieved through multiple-contact or dynamic miscibility, where the hydrocarbon with molecule at a medium and higher level than oil vaporize into $\mathrm{CO}_{2}$ (gas drive process), and a part of 
Proceeding on International Conference of Science Management Art Research Technology (IC-SMART), Vol. 1 (1), 33-43

The Potential of CO2 Injection on Enhanced Oil Recovery Method for Oil Fields in Indonesia Rini Setiati, Gilbert Soenarjo, Ixora Karundeng, Vicky Dimas Widoseno

injected $\mathrm{CO}_{2}$ will be dissolved into the oil (condensed gas drive process). Movement between oil and $\mathrm{CO}_{2}$ allows both phases to dissolve completely without interface tension whatsoever and help develop a dissolved transitional zone (Drahansky et al., 2016).

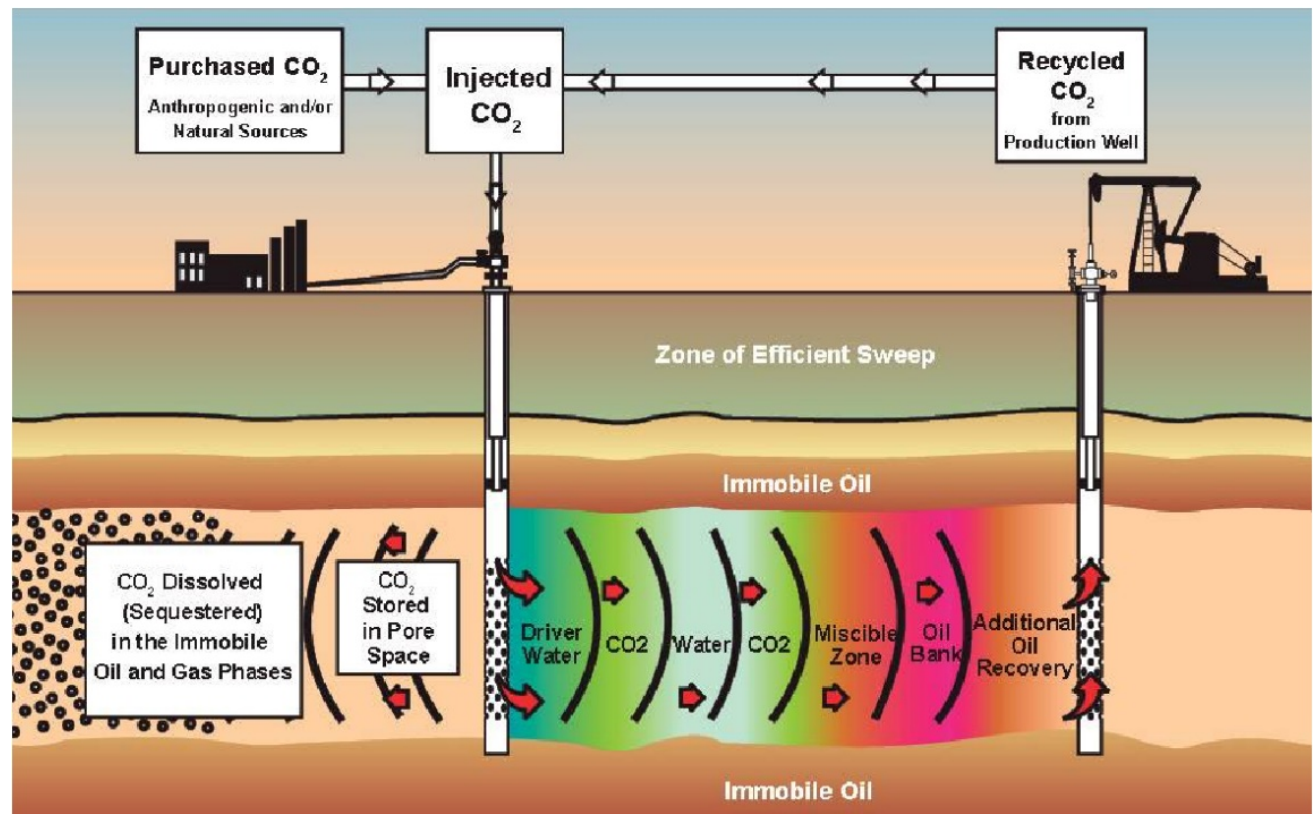

Figure 3. $\mathrm{CO}_{2}$ Miscible Mechanism (Advanced Resources International, 2010)

$\mathrm{CO}_{2}$ Immiscible Mechanism

This mechanism is utilized when the reservoir pressure level is below MMP, which inhibits $\mathrm{CO}_{2}$ and oil in the reservoir to form a single-phase (unmixed). However, the $\mathrm{CO}_{2}$ at this condition will be dissolved in oil and causes swelling or oil volume increase, which would lower viscosity and increase oil density (Drahansky et al., 2016).

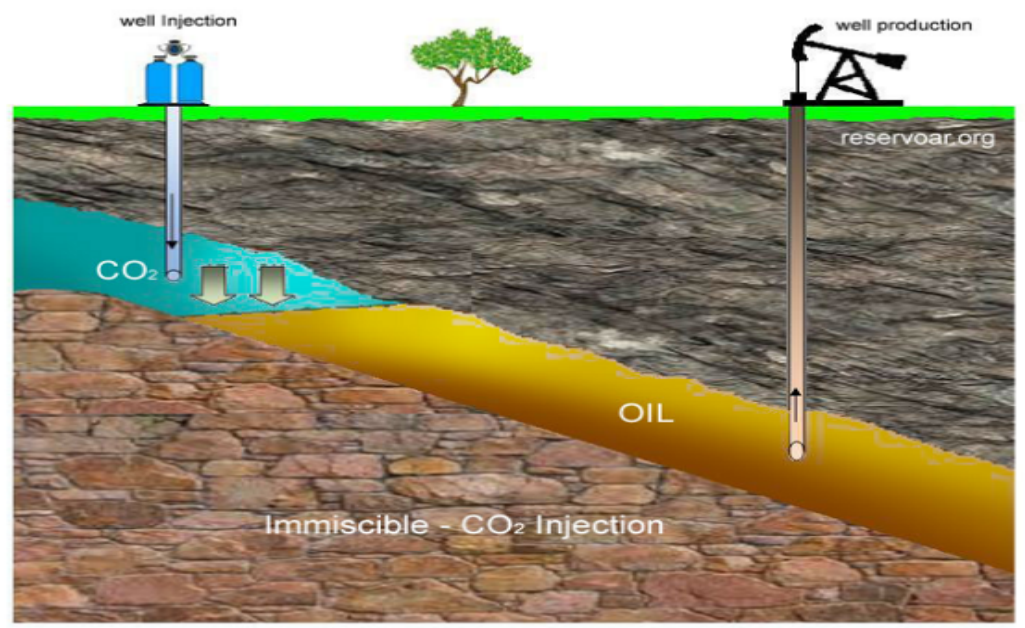

Figure 4. $\mathrm{CO}_{2}$ Immisicible Mechanism (Merchant, 2015) 


\section{RESEARCH METHODOLOGY}

Based on reservoir geological condition, fluid, and rock formation, there are several $\mathrm{CO}_{2}$ injection models, for example:

Continued $\mathrm{CO}_{2}$ injection during EOR process

This process requires a periodically $\mathrm{CO}_{2}$ injection without other fluid addition. Sometimes, nitrogen is also injected along with $\mathrm{CO}_{2}$ gas to improve sweeping effectiveness (UKCS Oil and Gas Authority, 2017).

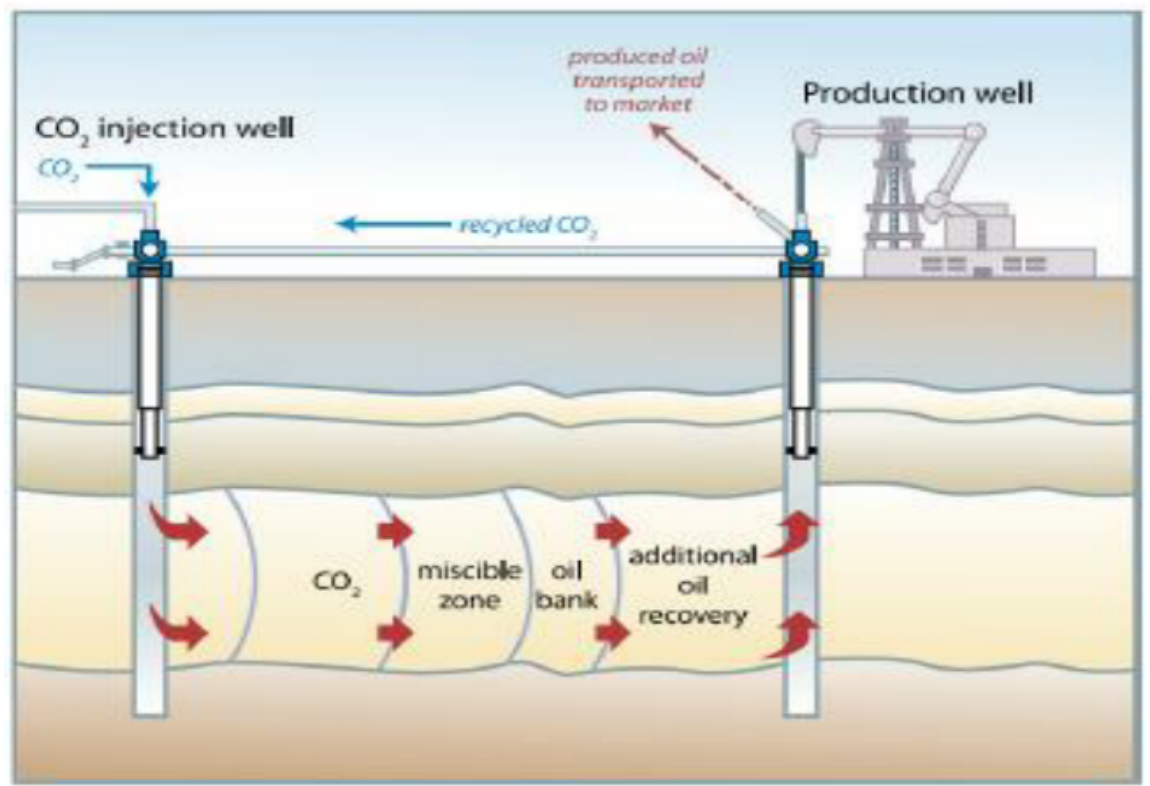

Figure 5. Continued $\mathrm{CO}_{2}$ Injection (H. Hawez, 2014)

$\mathrm{CO}_{2}$ Injection followed by water

This method is similar to $\mathrm{CO}_{2}$ method, but water is injected to add $\mathrm{CO}_{2}$ volume (UKCS Oil and Gas Authority, 2017). So after $\mathrm{CO}_{2}$ injection is conducted, the process continued to water injection, as illustrated in the following figure.

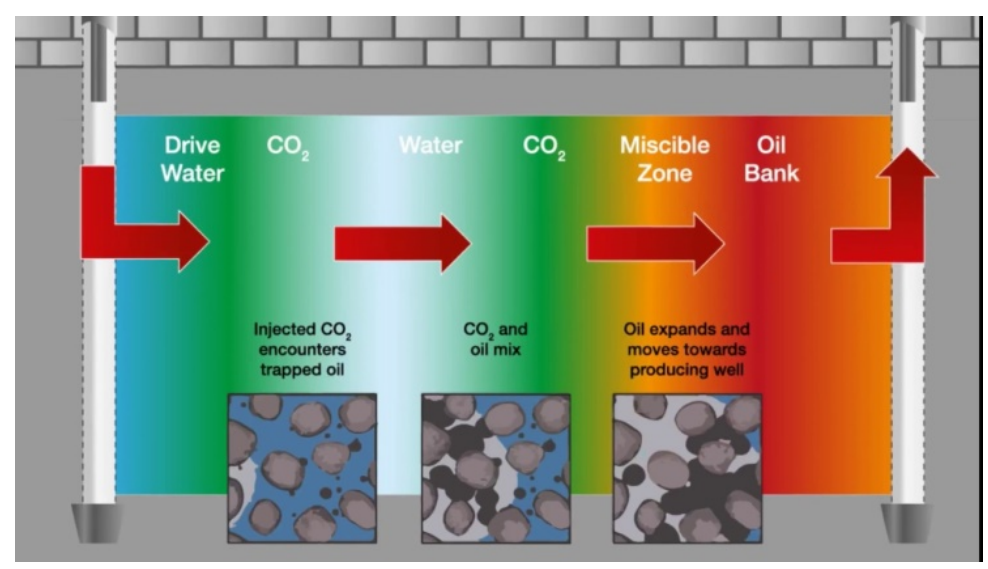

Figure 6. $\mathrm{CO}_{2}$ injection, followed by water injection (Lee, 2014) 
$\mathrm{CO}_{2}$ Injection periodically with water (conventional WAG)

In water-alternating-gas (WAG) process, a volume if $\mathrm{CO}_{2}$ is injected with a periodic cycle with water on a predetermined similar volume. Water is periodically injected with $\mathrm{CO}_{2}$ to help overcome gas override and lower excessive $\mathrm{CO}_{2}$ channeling, while also improve $\mathrm{CO}_{2}$ sweeping efficiency as a whole (Merchant, 2015).

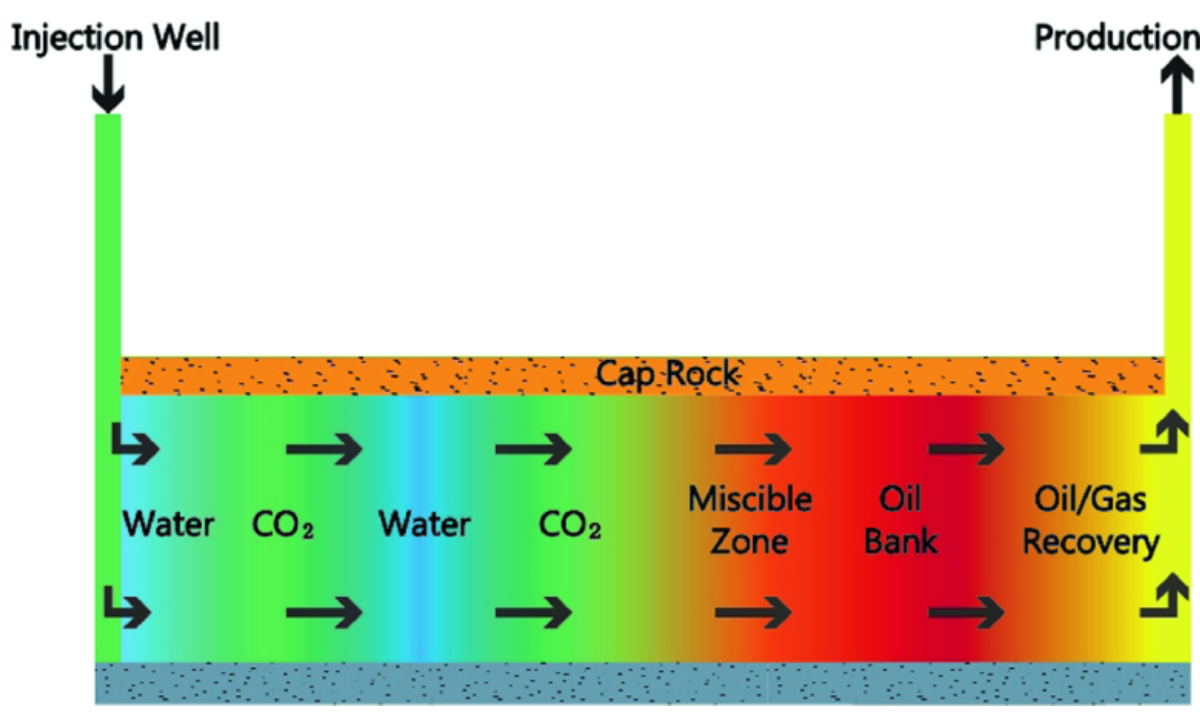

Figure 7. Water alternating gas (WAG) $\mathrm{CO}_{2}$ Flooding (Lee, 2014)

Periodically $\mathrm{CO}_{2}$ and water injection (WAG)

This method is similar to the conventional WAG method, but in this method, a gradual subtraction of $\mathrm{CO}_{2}$ injection is conducted relative to water injection volume (Merchant, 2010).

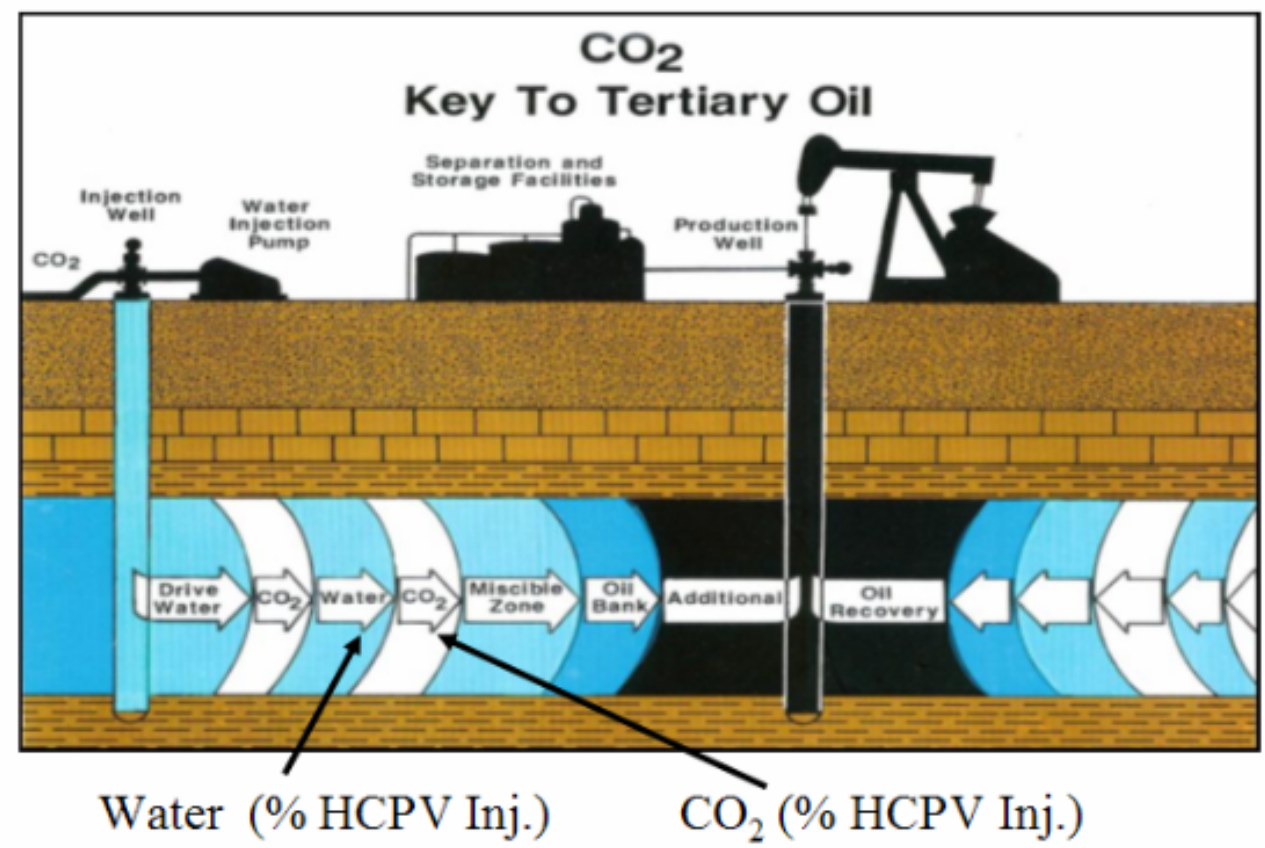

Figure 8. Periodically injection of $\mathrm{CO}_{2}$ and water (WAG) (Merchant, 2010) 
Proceeding on International Conference of Science Management Art Research Technology (IC-SMART), Vol. 1 (1), 33-43

The Potential of CO2 Injection on Enhanced Oil Recovery Method for Oil Fields in Indonesia Rini Setiati, Gilbert Soenarjo, Ixora Karundeng, Vicky Dimas Widoseno

In this research, the method utilized to improve the recovery factor or production capacity of a well is by conducting both secondary and tertiary gas injection recovery, especially $\mathrm{CO}_{2}$ injection.

In the injection of $\mathrm{CO}_{2}$ gas, a selection criterion that includes reservoir depth, pressure and temperature, minimum miscibility pressure (MMP), residual oil saturation, net pay density, crude oil gravity, viscosity, permeability, porosity, and reservoir heterogeneity (Huang et al., 2015). On initial screening, according to National Petroleum Board, the optimum criteria for $\mathrm{CO}_{2}$ miscible is summarized in Table 1 (Drahansky et al., 2016). Every deviation of these criteria will depend on reservoir size and its hydrocarbon recovery potential. For example, when reservoir temperature is higher than $120^{\circ} \mathrm{F}$, the additional pressure required in the process is between 200 to 500 psi to be able to reach miscibility. $\mathrm{CO}_{2}$ density depends on the depth of the injection, which controls the temperature and pressure around $0.6-0.8 \mathrm{~g} / \mathrm{cc}$. At this point, $\mathrm{CO}_{2}$ must be injected at $800 \mathrm{~m}$ of depth, where $\mathrm{CO}_{2}$ is at a solid phase (both liquid or supercritical). Reservoir with a high salinity level is more vulnerable to $\mathrm{CO}_{2}$ reserve than a low salinity reservoir (Al-Aryani, Obeidi, Brahmakulam, \& Ramamoorthy, 2011).

Table 1. Filter Criteria for CO2 Injection (Drahansky et al., 2016)

\begin{tabular}{|l|l|}
\hline \multicolumn{1}{|c|}{ Criteria } & \multicolumn{1}{|c|}{ Optimum condition } \\
\hline Depth, $\mathrm{ft}$ & $2500-3000$ \\
\hline Reservoir temperature, ${ }^{\circ} \mathrm{F}$ & $<120$ \\
\hline Total dissolved solids (TDS) $^{\prime}$ & $>3000$ \\
\hline Oil gravity & $<10,000 \mathrm{mg} / \mathrm{l}$ \\
\hline Oil viscosity, $\mathrm{cp}$ & Medium to light oils $\left(27-39^{\circ} \mathrm{API}\right)$ \\
\hline Reservoir type & Carbonate or Sandstone reservoar \\
\hline Minimum miscibility pressure (MMP) & $1300-2500 \mathrm{psi}$ \\
\hline Oil saturation & $>20 \%$ \\
\hline Net pay thickness, $\mathrm{ft}$ & $75-137$ \\
\hline Porosity & $>7 \%$ \\
\hline Permeability & $>10 \mathrm{mD}$ \\
\hline
\end{tabular}

The requirements in Table 1 act as references on reservoir data selection for $\mathrm{CO}_{2}$ injection to improve oil production capacity..

\section{FINDING AND DISCUSSION}

$\mathrm{CO}_{2}$ injection is one of the well-known EOR methods frequently utilized to improve oil recovery because of its relatively low cost. Also, $\mathrm{CO}_{2}$ possesses suitable characteristics for the EOR process. For example, it is easily dissolved in crude oil because of its light nature, and it has the ability to lower oil viscosity and also increase water viscosity, lower oil density, and form a fluid that mixed with oil because of the extraction process so it would be able to act as solution gas drive. $\mathrm{CO}_{2}$ injection source comes from wells that produce relatively pure $\mathrm{CO}_{2}$ or factories that process hydrocarbon gas that contains a vast amount of $\mathrm{CO}_{2}$ as a contaminant. $\mathrm{CO}_{2}$ injection also produces a positive impact on the environment because a part of $\mathrm{CO}_{2}$ (pollutant) is re-injected on the ground (Khalil \& Biyanto, 2018). $\mathrm{CO}_{2}$ injection has also been practiced in a geological formation, such as on old refineries all over the world. Principally, $\mathrm{CO}_{2}$ injection on the field is aimed to lower the surface tension between injection fluid and reservoir fluid, so that oil saturation can be produced (Stalkup, 1983). 
Proceeding on International Conference of Science Management Art Research Technology (IC-SMART), Vol. 1 (1), 33-43

The Potential of CO2 Injection on Enhanced Oil Recovery Method for Oil Fields in Indonesia Rini Setiati, Gilbert Soenarjo, Ixora Karundeng, Vicky Dimas Widoseno

Indonesia, as one of the numerous countries that produce oil, possesses numerous old refineries that have been operated for a long time. Oil production on these old fields can be improved by conducting $\mathrm{CO}_{2}$ injection as Enhanced Oil Recovery (EOR) process. There are many reservoirs in Indonesia that are profitable and suitable as $\mathrm{CO}_{2}$ (either mixed or unmixed) injection candidates. The produced oil is ranged from medium to light oils. Oil saturation after waterflood is high, and most of these wells are filled with water. Almost $62 \%$ of OOIP or 48.2 billion barrel of oil is available at the reservoirs. This accumulation is based on 650 oil fields targeted as EOR points (Usman, 2011). $\mathrm{CO}_{2}$ injection potential in Indonesian oil reservoirs is measured based on its available additional recovery capacity and $\mathrm{CO}_{2}$ source availability. There are oil and gas fields in Indonesia with a high level of $\mathrm{CO}_{2}$ content (for example, Natuna field), and sources of $\mathrm{CO}_{2}$ produced by oil-based power plants or LNG/LPG refineries, for example, the one located in Bontang/Arun. A screening process, laboratory test, and reservoir simulation modeling on several oil fields in Indonesia have been conducted. Sangatta field is an old reservoir with a production capacity that can be improved by $\mathrm{CO}_{2}$ injection. Besides that, the Sangatta field is very close to $\mathrm{CO}_{2}$ source, which is the LNG Bontang refinery, which is a high source of $\mathrm{CO}_{2}$. Figure 2 shows a map of the Sangatta field location, which is at $210 \mathrm{~km}$ north of Balikpapan City and $50 \mathrm{~km}$ of LNG Bontang refinery. Data utilized in this research are geological, reservoir, production, rock sample, and reservoir fluid data. Geologically, Sangatta possesses layered reservoirs with an anticline structure of $18 \mathrm{~km}^{2}$. Laterally, this field also possesses a complex fault system. The productive zone is located at Balikpapan formation with a depth of 500-1300 meters and in a lithological manner formed of sandstone covered by clay and coal. The number of located reservoirs is 277 reservoirs (layers) with an initial oil content of 261.3 million Bbl. The amount of produced oil up until the conduction of this research is at 31.6 million $\mathrm{Bbl}$ or around $12 \%$ of its initial oil content. With a reserve of $88 \%$ from initial content, Sangatta production capacity possesses the high potential to be improved and also utilized as a permanent $\mathrm{CO}_{2}$ reservation area. Based on the parameter screening, the Sangatta field possesses higher Minimum Miscibility Pressure than the initial reservoir pressure. MMP determination laboratory test was conducted on five injection pressure, which is at 2250, 2500, 2750,3000, and 3250 Psi. as shown in the following figure, oil recovery factors on 2250, 2500, and 2750 Psi of injection pressures show a steep increase, meanwhile on 3000 and 3250 Psi injection pressures, the increase is relatively low. Based on the calculation, there are two tendencies of oil recovery factor improvement on two categories of injection pressures which are at 2250, 2500, and 2750 Psi injection pressures and for 3000 and 3250 Psi injection pressures. MMP is determined by the intersection of two tendency lines, which shows 2850 Psi of pressure, as illustrated in the following figure. MMP value is higher than the estimated MMP produced with the correlation method on the screening process. MMP is an important parameter that can be utilized as reservoir simulation modeling data input. In this case, an approximate of 1763 Psi additional pressure for each reservoir to reach MMP is required, as shown in the following figure. The selected injection pressure is at 3000 Psi or 150 Psi higher than the MMP test result that shows $2850 \mathrm{Psi}$, to make sure that mixed pressure is above the required minimum pressure. 


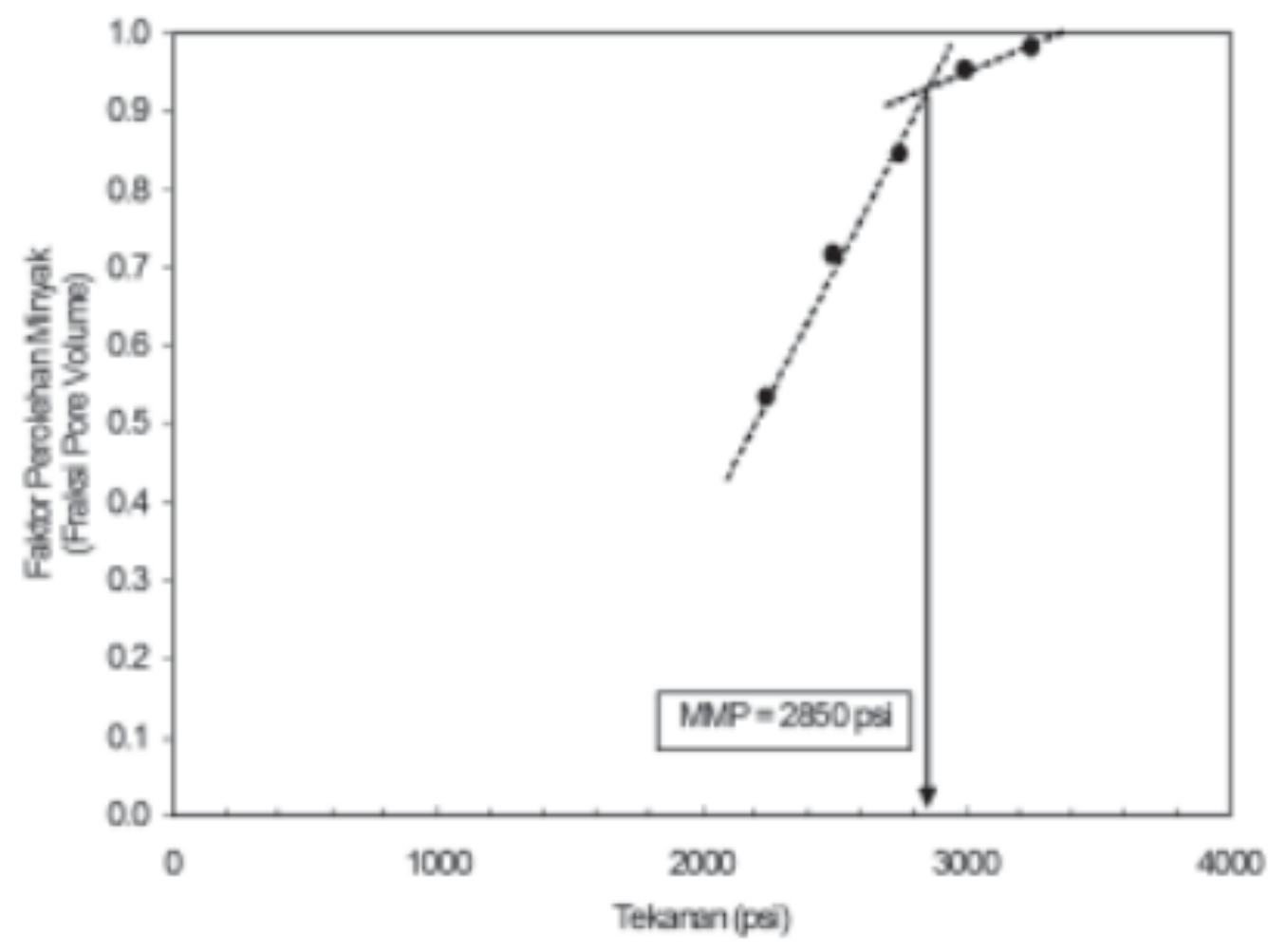

Figure 9. A laboratory test to determine minimum miscible pressure (Syahrial, 2009)

In Indonesia, oil fields are categorized into three areas, namely, west area, central area, and east area. West area includes North Sumatera, Central Sumatera, and Natuna. The central area includes South Sumatera and Java. Meanwhile, the east area includes Borneo, Sulawesi, and Papua. Oil fields in the west and central areas are generally mature fields. Almost $90 \%$ of Indonesian oil is produced in these areas, which is more than $86 \%$ of Indonesian oil reserves. In Sumatera, $\mathrm{CO} 2$ supply is provided by the gas field in Natuna (Block D Alpha), North Sumatera (Arun LNG), and South Sumatera (Muara Tengah, power plant, gas, and flare gas fields or several oil fields). In Java, $\mathrm{CO} 2$ can be supplied by gas processing factories (Subang, Merbau, Cimalaya), and in West Java, CO2 is produced from Muara Tawar Power Plant, several petrochemical industries, and flare gas from several oil fields. In Borneo, CO2 supply can be obtained from East Borneo (LNG Bontang, Muara Jawa Power Plant, and flare gas of several oil fields). In Sulawesi and Papua, CO2 supply can be sourced from Tangguh LNG, gas fields, and flare gas of several fields (Muslim, 2013). CO2 injection simulation has been conducted on several oil fields in Indonesia, as shown in the following table.

Table $2 \mathrm{CO}_{2}$ Injection Simulation Results on Oil Fields in Indonesia (Sugiharjo, 2012)

\begin{tabular}{|c|c|c|c|}
\hline No. & Field & MMP (psig) & Recovery Factor (\%) \\
\hline 1 & Attaka, East Kalimantan & 2150 & 90 \\
\hline 2 & Sanggata, East Kalimantan & 2800 & 93.26 \\
\hline 3 & Jati Barang, West Java & 2575 & 96.37 \\
\hline 4 & Tugu Barat, West Java & 3000 & 52.67 \\
\hline 5 & Kaji Semoga, South Sumatera & 2420 & 70.00 \\
\hline 6 & Jene, South Sumatera & 3200 & 91.33 \\
\hline
\end{tabular}


Proceeding on International Conference of Science Management Art Research Technology (IC-SMART), Vol. 1 (1), 33-43

The Potential of CO2 Injection on Enhanced Oil Recovery Method for Oil Fields in Indonesia Rini Setiati, Gilbert Soenarjo, Ixora Karundeng, Vicky Dimas Widoseno

$\mathrm{CO}_{2}$ injection method is divided into four parts. The first part is the continued $\mathrm{CO}_{2}$ injection. During this part, $\mathrm{CO}_{2}$ is also sometimes injected together with nitrogen. This method is aimed to maintain a better reservoir sweeping effectiveness and optimality. The second part is periodically $\mathrm{CO}_{2}$ and water injections. After the miscibility process between $\mathrm{CO}_{2}$ and crude oil is produced, formation water is injected to lower $\mathrm{CO}_{2}$ utilization to push oil to the surface. The third is $\mathrm{CO}_{2}$ injection, periodically with water injection (Water Alternating Gas conventional). On this $\mathrm{CO}_{2}$ injection method, the determined $\mathrm{CO}_{2}$ volume was injected on a periodic cycle along with similar water volume. $\mathrm{CO}_{2}$ injection in a periodic manner with water will help overcome gas override and lower excessive $\mathrm{CO}_{2}$ channeling while also improve $\mathrm{CO}_{2}$ sweeping efficiency as a whole. The last part is $\mathrm{CO}_{2}$ injection and water in a stimulant manner. This part is almost similar to Water Alternating Gas Conventional (WAG) method, but a gradual subtraction of $\mathrm{CO}_{2}$ injection volume is conducted relatively with water volume addition according to reservoir condition.

$\mathrm{CO}_{2}$ injection mechanism process is divided into two parts, namely the immiscible $\mathrm{CO}_{2}$ mechanism and miscible $\mathrm{CO}_{2}$ mechanism. The immiscible $\mathrm{CO}_{2}$ mechanism is a condition where reservoir pressure is lower than MMP pressure (Minimum Miscibility Pressure). MMP is ranged between $1300=2500$ Psi. MMP pressure will determine whether the injected fluid will react with crude oil or not or can flow through the rock pores. Because of the immiscible process, the reservoir pressure is higher than MMP. The injected $\mathrm{CO}_{2}$ gas will dissolve into the oil and increase oil volume also lower viscosity and increase oil density. With this mechanism, it will be easier to produce oil. The immiscible process is highly suitable to be utilized on reservoirs that contain heavy crude oil or commonly known as heavy oil. Miscible process $\mathrm{CO}_{2}$ injection is conducted when the reservoir pressure is higher than MMP pressure so that $\mathrm{CO}_{2}$ injection can mix together with crude oil and create a single phase. Miscibility between $\mathrm{CO}_{2}$ and crude oil can happen through multiple contacts, where heavy hydrocarbon with middle and high molecule weight vaporized into $\mathrm{CO}_{2}$, or commonly known as driver gas. Movement between oil and $\mathrm{CO}_{2}$ enables both phases to be mixed together into a complete single phase without any difference in its surface tension (Dessouky, 2018). During $\mathrm{CO}_{2}$ injection, the expected process is a miscible process so that $\mathrm{CO}_{2}$ injection doesn't have to be channeled with continuity. $\mathrm{CO}_{2}$ injection works maximally on 2500-3000 feet of depth, with reservoir temperature, not more than 120 degrees Fahrenheit.

\section{CONCLUSION AND FURTHER RESEARCH}

Based on the discussion and literature above, there are several conclusions made which are:

1. $\mathrm{CO}_{2}$ injection is a highly prospective EOR for Indonesia at the current moment with vast $\mathrm{CO}_{2}$ gas sources available from oil fields in Indonesia.

2. $\mathrm{CO}_{2}$ injection is a decent method to increase production rate in reservoir that contains heavy or light oil.

3. During light oil production improvement, $\mathrm{CO}_{2}$ injection must be conducted constantly to maintain the miscibility process between $\mathrm{CO}_{2}$ and crude oil. Meanwhile, during heavy oil recovery, pressure was delivered similarly to the reservoir condition so that $\mathrm{CO}_{2}$ bubbles will be produced on hydrocarbon, which functions as a driving power to improve oil recovery.

$\mathrm{CO}_{2}$ injection can improve crude oil production in a large number and lower gas emission pollution on the environment.

\section{REFERENCES}

Al-Aryani, F., Obeidi, A., Brahmakulam, J., \& Ramamoorthy, R. (2011). Pulsed neutron monitoring of the first CO2 EOR pilot in the Middle East. SPE Middle East Oil and Gas Show and Conference, MEOS, Proceedings, 2, 986-1000. https://doi.org/10.2118/141490-ms 
Annual Report 2005, Kansas Geolocical Survey - Suburface, http://www.kgs.ku.edu/Publications/Ann Rep05/05techniques.html

Ayirala, S. C., \& Yousef, A. A. (2015). A state-of-the-art review to develop injection-waterchemistry requirement guidelines for IOR/EOR projects. SPE Production and Operations, 30(1), 26-42. https://doi.org/10.2118/169048-PA

Carter L D (2011) Enhanced oil recovery \& CCS. United States Carbon Sequestration Council, Palo Alto.

Dessouky, S. M. (2018). Numerical Prediction of Oil Formation Volume Factor at Bubble Point for Black Petroleum \& Petrochemical Engineering Journal Numerical Prediction of Oil Formation Volume Factor at Bubble Point for Black and Volatile Oil Reservoirs Using Non- Linear Regression Models. (March).

Drahansky, M., Paridah, M. ., Moradbak, A., Mohamed, A. ., Owolabi, F. abdulwahab taiwo, Asniza, M., \& Abdul Khalid, S. H. . (2016). We are IntechOpen, the world's leading publisher of Open Access books Built by scientists, for scientists TOP $1 \%$. Intech, i(tourism), 13. https://doi.org/http://dx.doi.org/10.5772/57353

Ego Syahrial, Hadi Purnomo, 2009, Oil Production Improvement with CO2 Injection on Old Sangatta Oil Field in East Borneo, LEMBARAN PUBLIKASI LEMIGAS, VOL. 43. NO. 2, AGUSTUS 2009: 166 - 175, http://203.189.89.59/ojs/index.php/LPMGB/article/view/142/128

H. Hawez \& Z. Ahmed, 2014, Enhanced oil recovery by CO2 injection in carbonate reservoirs, Conference PaperinWIT Transactions on Ecology and the Environment - December 2014, DOI: 10.2495/ESUS140481

Huang, T., Yang, H., Liao, G., \& Zeng, F. (2015). Optimization of CO2 flooding strategy to enhance heavy oil recovery. Society of Petroleum Engineers - SPE Canada Heavy Oil Technical Conference 2015, CHOC 2015, 980-999. https://doi.org/10.2118/174480-ms

Khalil, M., \& Biyanto, T. R. (2018). Optimization of CO2 Captured and Distributed for Enhanced Oil Recovery.

Kun Sang Lee, Jinhyung Cho, Ji Ho Lee, 2014, CO2 Storage Coupled with Enhanced Oil Recovery, Springer, https://doi.org/10.1007/978-3-030-41901-1

Merchant, D. (2010). SPE-139516 "Life beyond 80 - A Look at Conventional WAG Recovery beyond $80 \%$ HCPV Injection in CO2 Tertiary Floods." Carbon Management Technology Conference 2015: Sustainable and Economical CCUS Options, CMTC 2015, 2, 1132-1141. https://doi.org/10.7122/440075-ms

Muslim, W. Bae, A.K Permadi, Suranto, Bambang Gunadi, D.D Saputra, R. Widyaningsih, T.A. Gunadi, 2013, Opportunities and Challenges of CO2 Flooding in Indonesia, OnePetro, SPE, https://www.onepetro.org/conference-paper/SPE-165847-MS

NETL. (2010). Carbon Dioxide Enhanced Oil Recovery. (March), 30.

Sugihardjo., et al. 2012. CO2 utilization for EOR at oil fields in Indonesia. http://www.ccop.or.th/eppm/projects/16/docs/INDONESIA_CO2-EOR-IOR.pdf

UKCS Oil and Gas Authority. (2017). Recovery Factor Benchmarking. Recovery Factor Benchmarking, (September).

Usman. 2011. The Potential of EOR Development to Improve Oil Recovery in Indonesia. Lembaran publikasi minyak dan gas bumi, 45 (2): 91-102.

Verma, M. K. (2015). Fundamentals of Carbon Dioxide-Enhanced Oil Recovery (CO2-EOR)-A Supporting Document of the Assessment Methodology for Hydrocarbon Recovery Using CO2EOR Associated with Carbon Sequestration. U.S. Geological Survey, 19. https://doi.org/https://dx.doi.org/10.3133/ofr20151071. 